\title{
Morphogenesis and forage accumulation of Urochloa ruziziensis under nitrogen and potassium fertilization management
}

\section{Morfogênese e acúmulo de forragem da Urochloa ruziziensis sob manejo de adubação nitrogenada e potássica}

\author{
Karla Rodrigues de Lima ${ }^{1 *}$; Carlos Augusto Brandão de Carvalho²; Flavio \\ Henrique Vidal Azevedo ${ }^{3}$; Fabio Prudêncio de Campos ${ }^{4}$; Aline Barros da Silva \\ Ana Carla Chaves Dias ${ }^{5}$
}

\begin{abstract}
The objective of this study was to evaluate the effect of nitrogen and potassium fertilization on the morphogenetic and structural characteristics and production of Urochloa ruziziensis in two summer seasons (summer 1, 2010-2011and summer 2, 2011-2012) and the autumn and spring of 2011. A randomized complete block design with four treatments $\left(0,120,240\right.$, and $360 \mathrm{~kg} \mathrm{ha}^{-1}$ year ${ }^{-1}$ of N and $\mathrm{K}_{2} \mathrm{O}$ ) and five replications was used, with repeated measurements in each season, in a split plot arrangement. The treatments were allocated to the plots and the seasons of the year to the subplots. The phyllochron (PHY), leaf appearance rate (LAR), leaf elongation rate (LER), stem elongation rate (SER), tiller population density (TPD), tiller appearance rate (TAR), tiller mortality rate (TMR), leaf growth rate (LGR), stem growth rate (SGR), senescence rate (SR), forage accumulation rate (FAR), and leaf accumulation rate (LAR) of Urochloa ruziziensis were evaluated. There was a positive quadratic effect for the PHY and ELR, with maximum values of 4.3 days leaf ${ }^{-1}$ and $0.43 \mathrm{~cm} \mathrm{tiller}^{-1}$ day $^{-1}$, respectively. While the SER increased linearly $\left(0.0012 \mathrm{~cm} \mathrm{day}^{-1} \mathrm{~kg}^{-1}\right.$ of $\mathrm{N}$ and $\left.\mathrm{K}_{2} \mathrm{O}\right)$ during summer 2 . The TPD, TAR, and TMR increased linearly (averages of 1.53 tillers $\mathrm{m}^{-2}, 0.04 \%$ and $0.02 \%$ per $\mathrm{kg}$ of $\mathrm{N}$ and $\mathrm{K}_{2} \mathrm{O}$, respectively) with nitrogen and potassium fertilization during spring and both summer seasons. The LGR, SGR, and SR also increased linearly with $\mathrm{N}$ and $\mathrm{K}_{2} \mathrm{O}$ application rates during summer 2 $\left(0.2809,0.0082\right.$, and $0.0411 \mathrm{~kg} \mathrm{DM} \mathrm{ha}^{-1} \mathrm{day}^{-1}$, per kg of $\mathrm{N}$ and $\mathrm{K}_{2} \mathrm{O}$, respectively), while the FAR and LAR increased in a quadratic positive form (maximum values of 175 and $129 \mathrm{~kg}$ dry matter (DM) $\mathrm{ha}^{-1}$, corresponding to 294 and $237 \mathrm{~kg} \mathrm{ha}^{-1}$ of $\mathrm{N}$ and $\mathrm{K}_{2} \mathrm{O}$, respectively) during summer 2. Urochloa ruziziensis is a forage plant with a high DM production capacity during the summer and a high seasonal forage production.
\end{abstract}

Key words: Tiller density. Leaf accumulation rate. Leaf elongation rate. Steam elongation rate.

\footnotetext{
${ }^{1}$ Prof $f^{a}$ Titular em Zootecnia, Instituto Educacional Santa Catarina, Faculdade Guaraí, Guaraí, TO, Brasil. E-mail: karla.rural@, yahoo.com.br

2 Prof., Instituto de Zootecnia, Departamento de Nutrição Animal e Pastagens, Universidade Federal Rural do Rio de Janeiro, UFRRJ, Seropédica, RJ, Brasil. E-mail: carloscarvalho_ufrrj@yahoo.com.br

3 Promotor Técnico, Agrocria Comércio e Indústria Ltda, Goiânia, GO, Brasil. E-mail: flavioufrrj@yahoo.com.br

4 Pequisador Científico em Nutrição de Ruminantes, Agência Paulista de Tecnologia dos Agronegócios, APTA, Nova Odessa, SP, Brasil. E-mail: fcampos@iz.sp.gov.br

5 Discentes, Curso de Doutorado do Programa de Pós-Graduação em Ciências, UFRRJ, Seropédica, RJ, Brasil. E-mail: aline_ barros2006@hotmail.com; anacarlacdias@gmail.com

* Author correspondence
} 


\section{Resumo}

O objetivo deste trabalho foi avaliar o efeito das adubações nitrogenada e potássica sobre as características morfogênicas e estruturais e de produção de Urochloa ruziziensis, em duas estações de verão (de 2010/2011 - verão 1; e de 2011/2012 - verão 2), outono e primavera de 2011. Foi utilizado o delineamento de blocos completos casualizados com quatro tratamentos $(0,120,240$ e $360 \mathrm{~kg}$ ha $^{-1}$ ano $^{-1}$ de $\mathrm{N}$ e $\mathrm{K}_{2} \mathrm{O}$ ) e cinco repetições, sob medidas repetidas no tempo (estações do ano), num arranjo de parcelas subdivididas. Os tratamentos foram alocados às parcelas e as estações do86rte ano às subparcelas. Foram avaliados o filocrono (FILO), as taxas de aparecimento de folhas, as taxas de alongamento de folhas (TAlF) e de colmos (TAlC), a densidade populacional de perfilhos (DPP), as taxas de natalidade (TNP) e mortalidade (TMP) de perfilhos, as taxas de crescimento de folhas (TCF) e de colmos (TCC) e de senescência (TS), e as taxas de acúmulo de forragem (TAF) e de folhas (TAcFol) de Urochloa ruziziensis. Houve efeito quadrático negativo para FILO e positivo TAlF, com valores mínimo de 4,3 dias folha ${ }^{-1}$ para $208 \mathrm{~kg} \mathrm{ha}^{-1}$ de $\mathrm{N}$ e de $\mathrm{K}_{2} \mathrm{O}$,e máximo de $0,43 \mathrm{~cm}$ perfilho ${ }^{-1}$ dia $^{-1}$ para 234 $\mathrm{kg} \mathrm{ha}^{-1}$ de $\mathrm{N}$ e $\mathrm{K}_{2} \mathrm{O}$, respectivamente, enquanto que a TAlC aumentou linearmente $\left(0,0012 \mathrm{~cm}^{2}\right.$ pefilhodia $^{-1}$ por kg de $\mathrm{Ne} \mathrm{K}_{2} \mathrm{O}$ ) durante o verão 2 . A DPP, as TNP e TMP aumentaram linearmente (médias de 1,53 perfilhos $\mathrm{m}^{-2}, 0,04 \%$ e $0,02 \%$ por $\mathrm{kg}$ de $\mathrm{Ne} \mathrm{K}_{2} \mathrm{O}$, respectivamente) com os tratamentos durante as estações de primavera e verões 1 e 2 . As TCF, TCCe TS também aumentaram linearmente às doses de $\mathrm{N}$ e $\mathrm{K}_{2} \mathrm{O}\left(0,2809 ; 0,0082\right.$ e $0,0411 \mathrm{~kg} \mathrm{ha}^{-1} \mathrm{dia}^{-1}$ de MS por kg de $\mathrm{N}$ e $\mathrm{K}_{2} \mathrm{O}$, respectivamente), enquanto as TAF e TAFol aumentaram de forma quadrática positiva (valores máximos de 175 e $129 \mathrm{~kg} \mathrm{ha}^{-1} \mathrm{dia}^{-1}$ de MS, correspondentes a 294 e $237 \mathrm{~kg} \mathrm{ha}^{-1} \mathrm{de} \mathrm{N} \mathrm{e} \mathrm{K}_{2} \mathrm{O}$, respectivamente) durante o verão 2. A Urochlo aruziziensis configura-se como planta forrageira de alta capacidade de produção de massa seca durante o verão e de alta estacionalidade de produção forrageira.

Palavras-chave: Densidade de perfilhos. Taxa de alongamento de folhas. Taxa de alongamento de colmos. Taxa de acúmulo de folhas.

\section{Introduction}

The intensive use of forages in Brazil has increased in recent years. According to the IBGE (2017), the forage area has decreased from 160.1 million hectares in 2006 to 149.2 million hectares in 2017, with a slight increase in the number of heads per hectare, from 1.10 to 1.15 , which is considered a low yield. Therefore, it is necessary to have knowledge of the essential management practices to achieve an effective and harmonious balance between the three major components of system efficiency: growth, use of produced forage, and conversion of forage input into animal product (Da SILVA, 2016).

The production potential of a fodder plant is determined by its genetic potential, but its yield is directly affected by the environmental conditions and management practices. Thus, knowledge of plant morphophysiologyis essential for the efficient management of forage and pasture, and research on morphogenesis has become an important method to assess leaf and tiller dynamics in pastures (SALES et al., 2014).

Most pastures in Brazil consist of grasses of the genus Urochloa. The species Urochloa decumbens cv. Basilisk and Urochloa brizantha cv. Marandu are currently the most used species (FONSECA; MARTUSCELLO, 2010). Urochloa ruziziensis occupies smaller areas of land but its use has been increasing, especially in agriculture cattle raising integration systems (ALVES, 2015; LIMA et al., 2016). However, no studies on the morphogenesis and accumulation of forage of this species could be found in the literature.

Studies on the morphophysiology of fodder plants have shown that there are complex interactions between the morphogenic characteristics of the canopy of tropical grasses and abiotic factors (management practices and environmental conditions) (GOMIDE et al., 2003). Among management practices, nitrogen and potassium fertilization has a direct effect on the dynamics of 
plant generations and the expansion of their form in space, promoting changes in the rates of leaf appearance, leaf elongation, leaf senescence, and stem elongation, as well as in the number of tillers and number of leaves per tiller (ALEXANDRINO et al., 2004; BASSO et al., 2010; BRAZ et al., 2011). Thus, because nitrogen and potassium fertilization alter the morphophysiology of fodder plants, it is pertinent to assess the responses of different fodder species to elucidate their canopy structures, behavior, and production potential.

In this sense, the objective of the present study was to assess the effects of different doses of nitrogen and potassium fertilizer on the morphogenic, structural, and dry matter (DM) accumulation characteristics of Urochloa ruziziensis, managed under the criterion of $95 \%$ light interception (LI) during the spring, summer, and autumn seasons.

\section{Material and Methods}

The experiment was conducted in the Experimental Field of the Department of Animal Nutrition and Pastures of the Husbandry Institute of the Universidade Federal do Rio de Janeiro, in Seropédica - RJ $\left(22^{\circ} 45^{\prime} \mathrm{S}\right.$ and $43^{\circ} 41^{\prime} \mathrm{W}, 33 \mathrm{~m}$ altitude), from December 21, 2010 to March 30, 2012. During this period, the characterized seasons were the summer (summer 1) of 2010/2011 (December 21, 2010 to March 25, 2011), autumn (March 25 to May 19 of 2011), spring (September 23 to December 13 of 2011) of 2011, and summer (summer 2) of 2011/2012 (December 14 of 2011 to March 30 of 2012).

The climate of the region is classified as type Aw (Köppen), with a dry season from April to September and a hot and rainy season from October to March. The means of the climatic data and water balance (THORNTHWAITE; MATHER, 1955) during the experimental period were obtained by the INMET (2012), based on data from the agricultural ecology station located in Seropédica - RJ (Table 1).

Table 1. Monthly mean maximum and minimum temperatures, total monthly rainfall, and monthly water balance between January 2010 and March 2012.

\begin{tabular}{|c|c|c|c|c|c|}
\hline \multirow{2}{*}{ Month/Year } & \multicolumn{2}{|c|}{ Air temperature $\left({ }^{\circ} \mathrm{C}\right)$} & \multirow{2}{*}{$\begin{array}{c}\text { Rainfall } \\
(\mathrm{mm})\end{array}$} & \multicolumn{2}{|c|}{ Monthly water balance (mm) } \\
\hline & Maximum & Minimum & & Deficit & Excess \\
\hline $\operatorname{Dec} / 2010$ & 31.2 & 23.1 & 223.2 & 0.0 & 66.1 \\
\hline $\mathrm{Jan} / 2011$ & 33.1 & 23.7 & 120.8 & -40.1 & 0.0 \\
\hline $\mathrm{Feb} / 2011$ & 33.5 & 22.0 & 48.2 & -112.0 & 0.0 \\
\hline Mar/2011 & 29.5 & 22.3 & 174.6 & 0.0 & 0.0 \\
\hline Apr/2011 & 29.0 & 19.8 & 102.4 & -4.2 & 0.0 \\
\hline May/2011 & 26.5 & 18.2 & 65.4 & -1.1 & 0.0 \\
\hline Jun/2011 & 23.8 & 14.3 & 39.2 & -3.9 & 0.0 \\
\hline $\mathrm{Jul} / 2011$ & 26.4 & 16.6 & 15.0 & -25.6 & 0.0 \\
\hline Aug/2011 & 28.2 & 17.5 & 24.6 & -35.0 & 0.0 \\
\hline Sep/2011 & 18.5 & 11.6 & 14.8 & -22.2 & 0.0 \\
\hline Oct/2011 & 26.9 & 18.6 & 106.8 & 0.0 & 0.0 \\
\hline Nov/2011 & 28.5 & 20.7 & 93.6 & -46.6 & 0.0 \\
\hline Dec/2011 & 33.0 & 25.0 & 234.0 & 0.0 & 0.0 \\
\hline $\mathrm{Jan} / 2012$ & 32.3 & 23.4 & 270.0 & 0.0 & 106.3 \\
\hline $\mathrm{Feb} / 2012$ & 33.5 & 22.0 & 42.6 & -23.5 & 0.0 \\
\hline Mar/2012 & 31.7 & 21.5 & 0.0 & -88.6 & 0.0 \\
\hline
\end{tabular}

Source: INMET (National Institute of Meteorology). 
The soil in the experimental area is classified as Haplic Planosol (RAMOS et al., 1973) and its chemical analysis (July 15, 2010) showed the following results: $\mathrm{pH}\left(\mathrm{H}_{2} \mathrm{O}\right)=5.6 ; \mathrm{MO}=22 \mathrm{~g} \mathrm{dm}^{-}$ 3; $\mathrm{Ca}\left(\mathrm{KCl} 1 \mathrm{~mol} \mathrm{~L}^{-1}\right)=3.6 \mathrm{Cmol}_{\mathrm{c}} \mathrm{dm}^{-3} ; \mathrm{Mg}(\mathrm{KCl}$ $\left.1 \mathrm{~mol} \mathrm{~L}^{-1}\right)=1.3 \mathrm{Cmol}_{\mathrm{c}} \mathrm{dm}^{-3} ; \mathrm{K}=0.3 \mathrm{Cmol}_{\mathrm{c}} \mathrm{dm}^{-3}$; $\mathrm{Na}=0.03 \mathrm{Cmol}_{\mathrm{c}} \mathrm{dm}^{-3}$; $\mathrm{Al}\left(\mathrm{KCl} 1 \mathrm{~mol} \mathrm{~L}^{-1}\right)=0.0$ $\mathrm{Cmol}_{\mathrm{c}} \mathrm{dm}^{-3} 3 \mathrm{H}+\mathrm{Al}=3.1 \mathrm{Cmol}_{\mathrm{c}} \mathrm{dm}^{-3} ; \mathrm{P}$ (Mehlich 1) $=20 \mathrm{mg} \mathrm{dm}^{-3} ; \mathrm{CEC}=8.3 \mathrm{Cmol}_{\mathrm{c}} \mathrm{dm}^{-3}$; and $63 \%$ base saturation. Based on these results, the experimental units were fertilized with $80 \mathrm{~kg} \mathrm{ha}^{-1}$ of $\mathrm{P}_{2} \mathrm{O}_{5}$, in the form of simple super phosphate on October 1, 2010, according to the recommendations of De Polli (1990).

The fodder species used in the experiment was Urochloa ruziziensis, whose experimental area was created in November 2008 and was composed of 20 plots of $8 \mathrm{~m}^{2}$ each (experimental unit). The plots were made uniform through cutting at a height of $10 \mathrm{~cm}$ from the ground, in the spring (December 11, 2010).

The treatments consisted of one control treatment (without fertilizer) and three different doses of fertilizer $\left(120,240\right.$, and $360 \mathrm{~kg} \mathrm{ha}^{-1} \mathrm{year}^{-1}$ of $\mathrm{N}$ and $\mathrm{K}_{2} \mathrm{O}$ ), divided in to five applications per year: three applications in the summer (December 17, 2010, January 7, 2011, and March 23, 2011) and two in the spring (October 11 and December 21, 2011). Each application comprised 24, 48, and $72 \mathrm{~kg} \mathrm{ha}^{-1}$ of $\mathrm{N}$ and $\mathrm{K}_{2} \mathrm{O}$ in the form of urea and potassium chloride, to make up annual treatments of 120, 240, and $360 \mathrm{~kg} \mathrm{ha}^{-1}$ of $\mathrm{N}$ and $\mathrm{K}_{2} \mathrm{O}$, as indicated by Portz et al. (2013).

The criterion for cutting was the interception of photosynthetically active radiation (95\% of IL), using a canopy analyzer (AccuPAR Linear PAR/ LAI Ceptometer, Model PAR-80). Twelve readings were taken above and below the forage canopy, simultaneously. Because of the high seasonality of forage production and slower growth during autumn, the criterion established for cutting in all treatments (95\% of IL) was not met by the plants in the treatment without fertilizer. Therefore, these plants were not cut during autumn and were only used to compare the means between treatments.

The morphogenic, structural, and forage accumulation variables were not assessed during spring because the canopies in the plots had not reached 95\% IL (criterion for cutting). Cutting was only performed at the end of spring, which did not allow for the evaluation of these characteristics, i.e., the evaluations of morphogenesis always started 7 days after cutting.

To assess the morphogenic variables and the dynamics of forage DM accumulation (growth and senescence rates), 10 tillers per plot were marked (divided in to two 50-cm long transects and the tillers were marked at every $10 \mathrm{~cm}$ along the transect, located in two diagonals of the experimental unit) that were representative of each experimental unit, and labelled with colored plastic rings. In each season of the year (summer 1, 2010 and 2011; autumn, 2011; and summer2, 2011 and 2012), the data collection period consisted of four consecutive assessments, starting 7 days after cutting in each season. The following measurements were made with a millimeter ruler: (a) length of the green leaf blade, from the apex (tip) of the leaf blade until the ligule of the last fully elongated leaf in the case of elongating leaves, and until the ligule of the leaf being measured in the case of fully elongated or senescing leaves; (b) length of the stem, from the insertion of the plant's crown when basal, and from the insertion of the lateral tillering stems with basal tillers when aerial, until the ligule of the last elongated leaf. These data were used to calculate the phyllochron (PHY), leaf elongation rate (LER), stem elongation rate (SER), senescence rate (SR), and number of leaves per tiller (LPT).

At the end of each season assessment, all marked tillers and another 100 tillers from each treatment were cut at ground level, stored in labelled plastic bags, and quickly taken to the sample preparation site. The sample was divided into green leaf blades, 
senescent and dead leaf blades, and green (living) stems. After the total length of all leaf blades and stems were measured with a millimeter ruler, all leaf blades and stems were dried in a forced-air oven at $55^{\circ} \mathrm{Cfor} 72$ hand subsequently weighed. The leaf growth rate (LGR), stem growth rate (SGR), senescence rate (TS), forage accumulation rate (FAR), and leaf accumulation rate (LAR) were estimated according to Bircham and Hodgson (1983).

The tiller population dynamics were evaluated in an area of $0.03 \mathrm{~m}^{2}$ (sampling unit) to determine the percentages of tiller appearance and mortality. Plastic rings were used to delimit areas representing each experimental site $\left(8 \mathrm{~m}^{2}\right.$ plot $)$. All tillers were labeled with colored plastic rings (a different color for each generation). The first assessment was performed 7 days after cutting and the subsequent assessments were performed at regular 15-day intervals in each season. This allowed the assessment of the tiller population density (TPD), tiller appearance rate (TAR), and tiller mortality rate (TMR) per generation. The TPDs considered for the calculation of growth rates were assessed by counting the number of tillers within a $0.09 \mathrm{~m}^{2}$ $(0.30 \times 0.30 \mathrm{~m})$ frame per experimental unit every 14 days.

The measurements were repeated in each season, with one treatment factor (dose of fertilizers) in a randomized complete block design with four treatments and five repetitions. Each block received one of the following amounts of nitrogen and potassium fertilizer per treatment: 0, 120, 240, and $360 \mathrm{~kg} \mathrm{ha}^{-1}$ year ${ }^{-1}$ of $\mathrm{N}$ and $\mathrm{K}_{2} \mathrm{O}$. The doses of $\mathrm{N}$ and $\mathrm{K}_{2} \mathrm{O}$ were assigned to the plots and the seasons were allocated to the subplots, in a splitplot arrangement. The data were analyzed using the MIXED procedure in Statistical Analysis System (SAS, 2004) software version 9.2. The Akaike information criterion (WOLFINGER, 1993) was used to select the covariance matrix. The effects of the $\mathrm{N}$ and $\mathrm{K}_{2} \mathrm{O}$ doses, season, and their interactions were considered fixed, and the effects of blocks and their interactions were considered random. The means of the treatments were estimated using the '1smeans' package and the comparison between them was performed using the probability of difference option (PDIFF; $P<0.05$ ). Regression analyses were performed using the PROC REG procedure $(P<0.05)$.

\section{Results and Discussion}

The interaction between fertilization and season $(P<0.05)$ had effects on the PHY, LER, SER, and SR (Table 2). During summer 1, the positive linear effect observed for the PHY possibly occurred because of the absence of rainfall; a severe water deficit was recorded during this assessment period, more specifically in February 2011 (Table 1). Normally, the PHY decreases with increasing doses of fertilizer (PEREIRA et al., 2011; POMPEU et al., 2010; BRAZ et al., 2011; SILVA et al., 2012). There was a negative quadratic effect in summer 2 , with values of PHY decreasing until an estimated level of fertilization of $208 \mathrm{~kg} \mathrm{ha}^{-1}$ of $\mathrm{N}$ and $\mathrm{K}_{2} \mathrm{O}$, corresponding to 4.3 days leaf $^{-1}$. This shows that doses greater than $200 \mathrm{~kg} \mathrm{ha}^{-1}$ of nitrogen and potassium fertilization do not favor the appearance of new leaves of Urochloa ruziziensis grass, even during the season of greatest growth (summer); they extrapolate the genetic potential of plant production. Silva et al. (2009) obtained a similar response pattern when they studied two species of Urochloa (U. brizantha cv. Marandu and $U$. decumbenscv. Basilisk) fertilized with four doses of $\mathrm{N}(0,75,150$, and $225 \mathrm{mg} \mathrm{dm}^{-3}$ ) in pots growing in a green house. They observed a quadratic effect, with a reduction up to a dose of $160 \mathrm{mg} \mathrm{dm}^{-3}$ of N. During autumn, there was a reduction in the PHY in the treatment with $360 \mathrm{~kg} \mathrm{ha}^{-1}$ year $^{-1}$ of fertilizer relative to in the treatment with $120 \mathrm{~kg} \mathrm{ha}^{-1}$ year $^{-1}$, which confirms the results presented in the literature (PEREIRA et al., 2011; SILVA et al., 2012). 
Table 2. Phylllochron (PHY), leaf elongation rate (LER), stem elongation rate (SER), and senescence rate (SR) of Urochloa ruziziensis according to the dose of nitrogen and potassic fertilization and season.

\begin{tabular}{|c|c|c|c|c|c|c|c|}
\hline \multirow{2}{*}{ Season } & \multicolumn{4}{|c|}{ Dose of $\mathrm{N}$ and $\mathrm{K}_{2} \mathrm{O}\left(\mathrm{kg} \mathrm{ha}^{-1}\right.$ year $\left.^{-1}\right)$} & \multirow{2}{*}{ SEM } & \multirow{2}{*}{ Equation } & \multirow{2}{*}{$R^{2}$} \\
\hline & 0 & 120 & 240 & 360 & & & \\
\hline \multicolumn{8}{|c|}{ PHY (daysleaf $\left.{ }^{1}\right)$} \\
\hline Summer1 & $5.5 \mathrm{~A}$ & $6.1 \mathrm{~B}$ & $5.5 \mathrm{~B}$ & $13.4 \mathrm{~A}$ & & $\hat{\mathrm{Y}}=4.16+0.0193 \mathrm{X}^{* *}$ & 0.55 \\
\hline Autumn & - & $12.7 \mathrm{aA}$ & $11.7 \mathrm{abA}$ & $11.2 \mathrm{bB}$ & 0.4 & - & - \\
\hline Summer 2 & $6.3 \mathrm{~A}$ & $4.3 \mathrm{C}$ & 4.7B & $5.3 \mathrm{C}$ & & $\hat{\mathrm{Y}}=6.403-0.0201 \mathrm{X}+0.0000483 \mathrm{X}^{2 * *}$ & 0.66 \\
\hline \multicolumn{8}{|c|}{ LER $\left(\mathrm{cm}\right.$ tiller ${ }^{-1}$ day $\left.^{-1}\right)$} \\
\hline Summer 1 & $0.32 \mathrm{~A}$ & $0.38 \mathrm{~B}$ & $0.40 \mathrm{~A}$ & $0.25 \mathrm{~B}$ & & $\hat{\mathrm{Y}}=0.2885+0.0016 \mathrm{X}-0.00000452 \mathrm{X}^{2 * *}$ & 0.70 \\
\hline Autumn & - & $0.16 \mathrm{bC}$ & $0.22 \mathrm{bB}$ & $0.31 \mathrm{aB}$ & 0.03 & - & - \\
\hline Summer 2 & $0.30 \mathrm{~A}$ & $0.48 \mathrm{~A}$ & $0.42 \mathrm{~A}$ & $0.44 \mathrm{~A}$ & & $\hat{Y}=0.316+0.0013 X-0.00000278 X^{2 * *}$ & 0.32 \\
\hline \multicolumn{8}{|c|}{ SER $\left(\mathrm{cm}\right.$ tiller ${ }^{-1}$ day $\left.^{-1}\right)$} \\
\hline Summer 1 & $0.11 \mathrm{~A}$ & $0.22 \mathrm{C}$ & $0.38 \mathrm{~A}$ & $0.09 \mathrm{C}$ & & $\hat{\mathrm{Y}}=0.1+0.002 \mathrm{X}-0.00000542 \mathrm{X}^{2 * *}$ & 0.68 \\
\hline Autumn & - & $0.38 \mathrm{bB}$ & $0.35 \mathrm{cA}$ & $0.52 \mathrm{aB}$ & 0.04 & - & - \\
\hline Summer 2 & $0.20 \mathrm{~A}$ & $0.48 \mathrm{~A}$ & $0.38 \mathrm{~A}$ & $0.72 \mathrm{~A}$ & & $\hat{Y}=0.226+0.0012 X^{* *}$ & 0.61 \\
\hline \multicolumn{8}{|c|}{ SR $\left(\mathrm{cm}\right.$ tiller-1 day $\left.^{-1}\right)$} \\
\hline Summer 1 & $0.09 \mathrm{~B}$ & $0.16 \mathrm{~A}$ & $0.22 \mathrm{~A}$ & $0.10 \mathrm{AB}$ & & $\hat{\mathrm{Y}}=0.0796+0.0013 \mathrm{X}-0.00000333 \mathrm{X}^{2 * *}$ & 0.40 \\
\hline Autumn & - & $0.04 \mathrm{aB}$ & $0.05 \mathrm{aC}$ & $0.06 \mathrm{aB}$ & 0.02 & - & - \\
\hline Summer 2 & $0.25 \mathrm{~A}$ & $0.10 \mathrm{AB}$ & $0.14 \mathrm{~B}$ & $0.16 \mathrm{~A}$ & & $\hat{Y}=0.16$ & - \\
\hline
\end{tabular}

Means followed by distinct uppercase letters in the same column (season effect) and by distinct lowercase letters in the same line (effect of doses only for autumn) differ by PDIFF $(P<0.05)$. SEM: standard error of the mean. * $(P<0.05)$ and $* *(P<0.01)$.

The LER fit positive quadratic regression models during the two summers, with estimated maximum values of 0.43 and $0.47 \mathrm{~cm} \mathrm{tiller}^{-1}$ day $^{-1}$. These results were obtained with doses of fertilizer corresponding to $177 \mathrm{~kg} \mathrm{ha}^{-1}$ and $234 \mathrm{~kg} \mathrm{ha}^{-1}$ of $\mathrm{N}$ and $\mathrm{K}_{2} \mathrm{O}$ in summers 1 and 2, respectively. These results are in line with those obtained by Alexandrino et al. (2004) and Silva et al. (2009) who also observed quadratic responses for the effect of $\mathrm{N}$ on the LER. This is because the LER is one of the morphogenic characteristics that most responds to nitrogen and potassium fertilization (OLIVEIRA et al., 2007; SILVA et al., 2009; BRAZ et al., 2011). The results for the LER demonstrate the significant role of the nutrients supplied by fertilization in the positive effect of this variable, because it may be attributed to the deposition of nutrients, especially nitrogen, in the areas of elongation and cell division of leaves, as was reported by Lopes et al. (2013). The positive effect related to biomass accumulation occurs because the increase in LER provides a larger photosynthetically active leaf area. However, Campos et al. (2016) observed that, in addition to growth, nitrogen fertilization accelerates the senescence of the grass Brachiaria brizantha $\mathrm{cv}$. Xaraés because the fibrous fractions increase proportionally to the physical structures and the pasture cycles accelerate plant maturation depending on the climatic variations to which they are subjected.

SER also followed a positive quadratic behavior in summer 1 , and fit a linear regression model in summer 2, with a rate of $0.0012 \mathrm{~cm}^{\text {tiller }}{ }^{-1}$ day $^{-1}$ per $\mathrm{kg}$ of $\mathrm{N}$ and $\mathrm{K}_{2} \mathrm{O}$. Because in summer 2 the plants were already adapted to the cutting management practice and fertilization, the responses obtained during this season more consistently demonstrated the response of this fodder plant to the implemented management strategies. Thus, during summer, the 
elongation of Urochloa ruziziensis stems was more responsive to nitrogen and potassium fertilization than that of the leaves.

The SR fit a quadratic regression model during summer 1, with an estimated maximum value of $0.20 \mathrm{~cm} \mathrm{tiller}^{-1}$ day $^{-1}$, obtained with $195 \mathrm{~kg} \mathrm{ha}^{-1}$ of $\mathrm{N}$ and $\mathrm{K}_{2} \mathrm{O}$ fertilizer. This behavior resulted from the reduction that also occurred in the LER and SER, when the doses of fertilizer exceeded those of maximum efficiency (close to $200 \mathrm{~kg} \mathrm{ha}^{-1}$ ) for the present study. In summer 2 , however, this variable did not fit a specific simple linear regression model, with a higher value $\left(0.25 \mathrm{~cm}_{\text {tiller }}^{-1}\right.$ day $\left.^{-1}\right)$ obtained for the control treatment.

The interaction between fertilization treatment and season had an effect $(\mathrm{P}<0.05)$ on the number of leaves per tiller (LPT), mean leaf length (MLL), TPD, TAR, and TMR (Table 3). In general, lower mean values of these variables were observed during autumn, especially for the annual $\mathrm{N}$ and $\mathrm{K}_{2} \mathrm{O}$ doses of $240 \mathrm{~kg} \mathrm{ha}^{-1}$ and $360 \mathrm{~kg} \mathrm{ha}^{-1}$.

Table 3. Number of leaves per tiller (LPT), mean leaf length (MLL), tiller population density (TPD), tiller appearance rate (TAR), and tiller mortality rate (TMR) of Urochloa ruziziensis according to the dose of nitrogen and potassium fertilization and season.

\begin{tabular}{|c|c|c|c|c|c|c|c|}
\hline \multirow[t]{2}{*}{ Season } & \multicolumn{4}{|c|}{ Dose of $\mathrm{N}$ and $\mathrm{K}_{2} \mathrm{O}\left(\mathrm{kg} \mathrm{ha}^{-1}\right.$ year $\left.^{-1}\right)$} & \multirow[t]{2}{*}{ SEM } & \multirow{2}{*}{$\begin{array}{c}\text { Equation } \\
0\end{array}$} & \multirow{2}{*}{$\begin{array}{c}\mathrm{R}^{2} \\
120\end{array}$} \\
\hline & 0 & 120 & 240 & 360 & & & \\
\hline \multicolumn{8}{|c|}{ LPT (leaves tiller-1) } \\
\hline Summer 1 & $3,1 \mathrm{~A}$ & $3,8 \mathrm{~A}$ & $4,0 \mathrm{~A}$ & $2,9 \mathrm{~B}$ & & $\hat{\mathrm{Y}}=3,4$ & \\
\hline Autumn & - & $3,6 \mathrm{aA}$ & $2,9 \mathrm{bB}$ & $3,2 \mathrm{abB}$ & 0,1 & - & \\
\hline Summer 2 & $3,3 \mathrm{~A}$ & $3,3 \mathrm{~A}$ & $3,3 \mathrm{~B}$ & $3,8 \mathrm{~A}$ & & $\hat{Y}=3,5$ & \\
\hline \multicolumn{8}{|c|}{$\operatorname{MLL}\left(\mathrm{cm} \mathrm{leaf}^{-1}\right)$} \\
\hline Summer 1 & $8,2 \mathrm{~A}$ & $9,3 \mathrm{~A}$ & $10,7 \mathrm{~A}$ & $8,1 \mathrm{~B}$ & & $\hat{\mathrm{Y}}=8,0738+0,0233 \mathrm{X}-0,0001 \mathrm{X}^{2 * *}$ & 0,43 \\
\hline Autumn & - & $7,5 \mathrm{bB}$ & $8,6 \mathrm{aB}$ & $8,2 \mathrm{aAB}$ & 0,4 & - & - \\
\hline Summer 2 & $7,0 \mathrm{~B}$ & $10,5 \mathrm{~A}$ & $9,5 \mathrm{~B}$ & $9,6 \mathrm{~A}$ & & $\hat{Y}=6,836+0,0262 X-0,0000416 X^{2 * *}$ & 0,83 \\
\hline \multicolumn{8}{|c|}{ TPD (tillers $\left.\mathrm{m}^{-1}\right)$} \\
\hline Summer 1 & $566 \mathrm{~B}$ & $826 \mathrm{~B}$ & 893B & $1341 \mathrm{~A}$ & 65,9 & $\hat{\mathrm{Y}}=571,39+1,643 \mathrm{X}^{* *}$ & 0,79 \\
\hline Autumn & - & $112 \mathrm{cD}$ & $123 b D$ & $150 \mathrm{aC}$ & 3,4 & - & - \\
\hline Spring. & $732 \mathrm{~A}$ & $967 \mathrm{~A}$ & $1013 \mathrm{~A}$ & $1362 \mathrm{~A}$ & 54,3 & $\hat{\mathrm{Y}}=714,42+1,6618 \mathrm{X}^{* *}$ & 0,73 \\
\hline Summer 2 & $368 \mathrm{C}$ & $445 \mathrm{C}$ & $493 \mathrm{C}$ & $867 \mathrm{~B}$ & 44,4 & $\hat{\mathrm{Y}}=311,6+1,288 \mathrm{X}^{* *}$ & 0,64 \\
\hline \multicolumn{8}{|c|}{ TAR $(\%)$} \\
\hline Summer 1 & $10,4 \mathrm{~B}$ & $13,2 \mathrm{C}$ & $18,1 \mathrm{~B}$ & $29,8 \mathrm{~B}$ & 1,2 & $\hat{\mathrm{Y}}=8,3922+0,00528 \mathrm{X}^{* *}$ & 0,81 \\
\hline Autumn & - & $10,1 \mathrm{bA}$ & $12,8 \mathrm{aC}$ & $13,5 \mathrm{aD}$ & 0,6 & - & - \\
\hline Spring. & $13,5 \mathrm{~A}$ & $15,9 \mathrm{~B}$ & $20,3 \mathrm{AB}$ & $25,3 \mathrm{C}$ & 0,8 & $\hat{\mathrm{Y}}=12,862+0,0329 \mathrm{X}^{* *}$ & 0,86 \\
\hline Summer 2 & $16,6 \mathrm{~A}$ & $22,1 \mathrm{~A}$ & $23,7 \mathrm{~A}$ & $47,3 \mathrm{~A}$ & 2,2 & $\hat{\mathrm{Y}}=13,392+0,0781 \mathrm{X}^{* *}$ & 0,67 \\
\hline \multicolumn{8}{|c|}{ TMR (\%) } \\
\hline Summer 1 & $8,5 \mathrm{~B}$ & $9,2 \mathrm{BC}$ & $10,1 \mathrm{~B}$ & $13,5 \mathrm{~B}$ & 0,4 & $\hat{Y}=7,9194+0,0133 X^{* *}$ & 0,69 \\
\hline Autumn & - & $8,5 \mathrm{cC}$ & $9,6 \mathrm{bB}$ & $10,5 \mathrm{aC}$ & 0,3 & - & - \\
\hline Spring. & $7,8 \mathrm{~B}$ & $9,5 \mathrm{~B}$ & $11,9 \mathrm{~A}$ & $16,6 \mathrm{~A}$ & 0,4 & $\hat{\mathrm{Y}}=6,862+0,0248 \mathrm{X}^{* *}$ & 0,89 \\
\hline Summer 2 & $10,8 \mathrm{~A}$ & $12,3 \mathrm{~A}$ & $12,9 \mathrm{~A}$ & $18,6 \mathrm{~A}$ & 0,9 & $\hat{\mathrm{Y}}=10,098+0,0198 \mathrm{X}^{* *}$ & 0,56 \\
\hline
\end{tabular}

Means followed by distinct uppercase letters in the same column (season effect) and by distinct lowercase letters in the same line (effect of doses only for autumn) differ by PDIFF $(P<0.05)$. SEM: standard error of the mean. $*(P<0.05)$ and $* *(P<0.01)$. 
The number of LPT did not fit a regression model during summers 1 and 2, with a mean value of 3.4 and 3.5 leaves tiller ${ }^{-1}$, respectively. However, Silva et al. (2009) obtained a quadratic response to four doses of nitrogen $\left(0,75,150\right.$, and $\left.225 \mathrm{mg} \mathrm{dm}^{-3}\right)$ with Urochlo abrizantha cv. Marandu and Urochloa decumbens cv. Basilisk, and obtained a maximum of 9.3 leaves tiller ${ }^{-1}$, corresponding to the $157 \mathrm{mg}$ $\mathrm{dm}^{-3}$ dose of N. Teixeira et al. (2014), evaluating the morphogenetic and structural characteristics of Brachiaria decumbens pastures to determine nitrogen fertilization strategies, more adequate for deferred grazing, did not observe the effect of nitrogen fertilization on the different levels used, similar to the present study.. The lack of response from Urochloa ruziziensis to this fertilization was probably due to the more rigorous genetic control of this fodder plant regarding this variable relative to other species of the same genus. During autumn, there was a decrease in LFT from 3.6 to 2.9 when the fertilizer dose increased from 120 to $240 \mathrm{~kg} \mathrm{ha}^{-1}$ year ${ }^{1}$. However, the result was 3.2 LFT when the dose was $360 \mathrm{~kg} \mathrm{ha}^{-1}$ year $^{-1}$, similar to the $\mathrm{N}$ and $\mathrm{K}_{2} \mathrm{O}$ doses of 120 and $240 \mathrm{~kg} \mathrm{ha}^{-1}$ year $^{-1}$.

The MLL it a positive quadratic model during summers 1 and 2, with values of 9.4 and $11.0 \mathrm{~cm}$, corresponding to $\mathrm{N}$ and $\mathrm{K}_{2} \mathrm{O}$ fertilizer doses of 117 $\mathrm{kg} \mathrm{ha} \mathrm{h}^{-1}$ and $315 \mathrm{~kg} \mathrm{ha}^{-1}$, respectively. A different result was obtained by Alexandrino et al. (2004) on Urochloa brizantha cv. Marandu with three doses of nitrogen fertilizer $\left(0,20\right.$, and $40 \mathrm{mg} \mathrm{dm}^{-3}$ week$\left.{ }^{1}\right)$. They observed a positive linear effect for this variable. The MLL behavior followed the same trend as that of the LER, as it is also a consequence of the latter. During autumn, higher MLL values ( 8.6 and 8.2 versus $7.5 \mathrm{~cm} \mathrm{leaf}^{-1}$ ) were observed with the highest doses $\left(240 \mathrm{~kg} \mathrm{ha}^{-1}\right.$ year $^{1}$ and 360 versus $120 \mathrm{~kg} \mathrm{ha}^{-1}$ year $^{-1}$ of $\mathrm{N}$ and $\mathrm{K}_{2} \mathrm{O}$ ).

The TPD fit positive linear regression models during summer 1, spring, and summer 2 (mean rate of 1.53 tillers $\mathrm{kg}^{-1}$ of $\mathrm{N}$ and $\mathrm{K}_{2} \mathrm{O}$ ), which shows that this variable benefited from the effects of increasing the fertilizer dose. A higher density of tillers was recorded during spring, followed by summer 1 and summer 2. During autumn, despite the lower absolute values, this variable also increased at the highest tested doses, with a maximum value of 150 tillers $\mathrm{m}^{-2}$ at $360 \mathrm{~kg} \mathrm{ha}^{-1}$ of $\mathrm{N}$ and $\mathrm{K}_{2} \mathrm{O}$. This increase in TPD with increasing doses of $\mathrm{N}$ and $\mathrm{K}_{2} \mathrm{O}$ was mainly the result of the fact that $\mathrm{N}$ increases chlorophyll content in the leaves, which in turn increases the availability of photoassimilates, and there by influences the structural characteristics of the pasture (COLOZZA et al., 2000), such as the number of tillers, via the development of growth buds (basal or lateral) (NABINGER, 1996). The results obtained in the present study confirm those described by Morais et al. (2006) who observed a positive linear effect of fertilization on the TPD of Urochloa decumbens and attributed this behavior to site filling (the ratio of tillers to leaf appearances) with increased N. In addition, both Moreira et al. (2009) and Fagundes et al. (2005b) tested four doses of $\mathrm{N}\left(75,150,225\right.$, and $300 \mathrm{~kg} \mathrm{ha}^{-1}$ year $\left.{ }^{-1}\right)$ on Urochloa decumbens cv. Basilisk and reported a positive linear effect of nitrogen fertilization on this variable. Considering that the TPD is a structural characteristic of great importance, because it interferes with both the accumulation of forage and the intake of DM by animals (HODGSON, 1990), it is an indicator of a more or less lenient management, depending on their new strategies and on the tiller population of each fodder plant. In the case of Urochloa ruziziensis, autumn is the limiting season for tillering and/or longevity of the plant in its pasture areas if the management is not adequate (more lenient) during this season.

The TAR fit positive linear regression models during summer 1, spring, and summer 2. According to Oliveira et al. (2007), this behavior occurs because nitrogen fertilization is associated with growth stimulation and the multiplication of plant cells ( $\mathrm{N}$ is the main constituent of cellular proteins and nucleic acids). During autumn, the values of this variable were also higher with treatment doses of $240 \mathrm{~kg} \mathrm{ha}^{-1}$ and $360 \mathrm{~kg} \mathrm{ha}^{-1}$ of $\mathrm{N}$ and $\mathrm{K}_{2} \mathrm{O}$, compared 
to with lower doses. These results are in accordance with those obtained by Basso et al. (2010), who also demonstrated a higher tiller appearance with higher doses of N. Similarly, the TMR fit positive linear regression models during the same seasons and increased within creasing fertilizer doses in autumn. This demonstrates the effect of nitrogen and potassium fertilization on TMR, which may be related to the actions of $\mathrm{N}$ and $\mathrm{K}$ on both the growth of existing tillers and on the appearance of new tillers. This is probably because of self-shading and the subsequent death of the tillers that compose the community of plants (BULLOCK, 1996). Although mortality increased with increasing doses of fertilizer, the appearance rates were higher than the former and compensated (buffered) this behavior, thereby increasing the TPD. This fact reveals the strategy of continuous tiller renewal in Urochloa ruziziensis canopies, especially at the highest doses of $\mathrm{N}$ and $\mathrm{K}_{2} \mathrm{O}$ and during summer 2 . This pattern of behavioris a mechanism essential to the maintenance of the tiller population, and mostly to the survival of the plants in their ecosystem (MORAIS et al., 2006).

The interaction between the fertilization amount and season had effects $(P<0.05)$ on the LGR, SGR, SR, FAR, and LAR (Table 4). Lower values of these variables were obtained in autumn, mostly because of the lower availability of environmental growth factors during this season (Table 1).

Table 4. Leaf growth rate (LGR), stem growth rate (SGR), senescence rate (SR), forage accumulation rate (FAR), and leaf accumulation rate (LAR) of Urochloa ruziziensis according to the dose of nitrogen and potassium fertilization and season.

\begin{tabular}{|c|c|c|c|c|c|c|c|}
\hline \multirow{2}{*}{ Season } & \multicolumn{4}{|c|}{ Dose of $\mathrm{N}$ and $\mathrm{K}_{2} \mathrm{O}\left(\mathrm{kg} \mathrm{ha}^{-1} \mathrm{year}^{-1}\right)$} & \multirow{2}{*}{ SEM } & \multirow{2}{*}{ Equation } & \multirow{2}{*}{$\mathrm{R}^{2}$} \\
\hline & 0 & 120 & 240 & 360 & & & \\
\hline \multicolumn{8}{|c|}{ LGR $\left(\mathrm{kg} \mathrm{DM} \mathrm{ha}^{-1} \mathrm{day}^{-1}\right)$} \\
\hline Summer 1 & $32.0^{\mathrm{B}}$ & $76.7^{\mathrm{B}}$ & $86.2^{\mathrm{B}}$ & $27.8^{\mathrm{B}}$ & & $\hat{Y}=30.389+0.6418 X-0.0018 X^{2 * *}$ & 0.96 \\
\hline Autumn & - & $2.8^{\mathrm{bC}}$ & $4.3^{\mathrm{aC}}$ & $5.0^{\mathrm{aC}}$ & 1.9 & - & - \\
\hline Summer 2 & $47.4^{\mathrm{A}}$ & $109.8^{\mathrm{A}}$ & $121.4^{\mathrm{A}}$ & $154.9^{\mathrm{A}}$ & & $\hat{\mathrm{Y}}=57.581+0.2809 \mathrm{X}^{* *}$ & 0.90 \\
\hline \multicolumn{8}{|c|}{ SGR $\left(k g\right.$ DM ha $^{-1}$ day $\left.^{-1}\right)$} \\
\hline Summer 1 & $9.1^{\mathrm{B}}$ & $25.2^{\mathrm{A}}$ & $42.7^{\mathrm{A}}$ & $41.0^{\mathrm{B}}$ & & $\hat{\mathrm{Y}}=12.548+0.0934 \mathrm{X}^{* *}$ & 0.82 \\
\hline Autumn & - & $1.8^{\mathrm{bB}}$ & $2.6^{\mathrm{bB}}$ & $3.9^{\mathrm{aC}}$ & 2.2 & - & - \\
\hline Summer 2 & $34.6^{\mathrm{A}}$ & $28.3^{\mathrm{A}}$ & $42.1^{\mathrm{A}}$ & $62.2^{\mathrm{A}}$ & & $\hat{Y}=26.896+0.0082 X^{* *}$ & 0.55 \\
\hline \multicolumn{8}{|c|}{$\mathrm{SR}\left(\mathrm{kg} \mathrm{DM} \mathrm{ha}^{-1} \mathrm{day}^{-1}\right)$} \\
\hline Summer 1 & $6.4^{\mathrm{A}}$ & $15.1^{\mathrm{A}}$ & $17.0^{\mathrm{B}}$ & $12.4^{\mathrm{B}}$ & & $\hat{\mathrm{Y}}=9.7434+0.0166 \mathrm{X}^{* *}$ & 0.27 \\
\hline Autumn & - & $0.4^{\mathrm{bC}}$ & $0.6^{\mathrm{bC}}$ & $0.8^{\mathrm{bC}}$ & 0.5 & - & - \\
\hline Summer 2 & $7.9^{\mathrm{A}}$ & $9.4^{\mathrm{B}}$ & $18.6^{\mathrm{A}}$ & $20.8^{\mathrm{A}}$ & & $\hat{Y}=6.6556+0.0411 X^{* *}$ & 0.88 \\
\hline \multicolumn{8}{|c|}{ FAR $\left(\mathrm{kg} \mathrm{DM} \mathrm{ha}^{-1}\right.$ day $\left.^{-1}\right)$} \\
\hline Summer 1 & $34.8^{\mathrm{B}}$ & $86.7^{\mathrm{B}}$ & $111.9^{\mathrm{B}}$ & $56.3^{\mathrm{B}}$ & & $\hat{Y}=32.087+0.7471 X-0.0019 X^{2 * *}$ & 0.92 \\
\hline Autumn & - & $4.2^{\mathrm{cC}}$ & $6.3^{\mathrm{bC}}$ & $8.1^{\mathrm{aC}}$ & 3.3 & - & - \\
\hline Summer 2 & $74.6^{\mathrm{A}}$ & $133.4^{\mathrm{A}}$ & $173.7^{\mathrm{A}}$ & $162.8^{\mathrm{A}}$ & & $\hat{Y}=71.405+0.7046 X-0.0012 X^{2 * *}$ & 0.91 \\
\hline \multicolumn{8}{|c|}{ LAR(kg DM ha-1 day $\left.^{-1}\right)$} \\
\hline Summer 1 & $25.6^{\mathrm{B}}$ & $61.6^{\mathrm{B}}$ & $69.2^{\mathrm{B}}$ & $15.3^{\mathrm{B}}$ & & $\hat{\mathrm{Y}}=23.976+0.5419 \mathrm{X}-0.00166 \mathrm{X}^{2 * *}$ & 0.95 \\
\hline Autumn & - & $2.4^{\mathrm{aC}}$ & $3.7^{\mathrm{aC}}$ & $4.2^{\mathrm{aC}}$ & 1.9 & - & - \\
\hline Summer 2 & $39.8^{\mathrm{A}}$ & $91.3^{\mathrm{A}}$ & $145.4^{\mathrm{A}}$ & $100.6^{\mathrm{A}}$ & & $\hat{Y}=33.924+0.8065 X-0.0017 X^{2 * *}$ & 0.89 \\
\hline
\end{tabular}

Means followed by distinct uppercase letters in the same column (season effect) and by distinct lowercase letters in the same line (effect of doses only for autumn) differ by PDIFF $(P<0.05)$. SEM: standard error of the mean. $*(P<0.05)$ and $* *(P<0.01)$. 
The LGR showed a positive quadratic response to nitrogen and potassium fertilization during summer 1, with an estimated maximum rate of 87 $\mathrm{kg} \mathrm{ha}^{-1}$ day $^{-1}$ of DM, corresponding to $178 \mathrm{~kg} \mathrm{ha}^{-1}$ of $\mathrm{N}$ and $\mathrm{K}_{2} \mathrm{O}$ during summer 2, a positive linear result was obtained, which is in accordance with that reported by Fagundes et al. (2005a) with Urochloa decumbens, thereby confirming the positive effect of nitrogen and potassium fertilization on the LGR. During autumn, the response of the LGR was similar to that during summer 2, with higher values observed with higher doses of fertilizer $\left(120 \mathrm{~kg}^{-1}\right.$ $\mathrm{ha}^{-1}$ year and $360 \mathrm{~kg}^{-1} \mathrm{ha}^{-1}$ year of $\mathrm{N}$ and $\mathrm{K}_{2} \mathrm{O}$ ).

The SGR showed a positive linear response to increasing doses of fertilizer during summers 1 and 2 , and also to the highest dose (360 kg ha-1) of $\mathrm{N}$ and $\mathrm{K}_{2} \mathrm{O}$ during autumn, which indicates that this variable was responsive to the increased doses of nitrogen and potassium fertilizer in all of the studied seasons. These results are in accordance with those obtained by Martuscello et al. (2005) in a study on Brachiaria brizantha $\mathrm{cv}$. Xaraés using four doses of $\mathrm{N}\left(0,40,80\right.$, and $\left.120 \mathrm{mg} \mathrm{dm}^{-3}\right)$ and three regimens of defoliation (two, four, and five fully elongated leaves before cutting). They observed a linear increase in the SGR with increasing doses of N.

The response pattern of the SR was similar to that of the SGR, i.e., a positive linear response with increasing levels of fertilizer in summers 1 and 2 . This can be explained by the greater renewal of tissues in plants fertilized with $\mathrm{N}$, as described by Martuscello et al. (2005).

The FAR and LAR fit quadratic regression models with estimated maximum DM values of $106 \mathrm{~kg} \mathrm{ha}^{-1}$ day $^{-1}$ and $175 \mathrm{~kg} \mathrm{ha}^{-1}$ day $^{-1}$ (corresponding to $197 \mathrm{~kg}$ $\mathrm{ha}^{-1}$ and $294 \mathrm{~kg} \mathrm{ha}^{-1}$ of $\mathrm{N}$ and $\mathrm{K}_{2} \mathrm{O}$ ) for the FAR, and $68 \mathrm{~kg} \mathrm{ha}^{-1}$ day $^{-1}$ and $129 \mathrm{~kg} \mathrm{ha}^{-1}$ day $^{-1}$ (corresponding to $163 \mathrm{~kg} \mathrm{ha}^{-1}$ and $237 \mathrm{~kg} \mathrm{ha}^{-1}$ of $\mathrm{N}$ and $\mathrm{K}_{2} \mathrm{O}$ ) for LAR, during summers 1 and 2, respectively. During autumn, higher values of FAR were obtained with $360 \mathrm{~kg} \mathrm{ha}^{-1}$ and $240 \mathrm{~kg} \mathrm{ha} \mathrm{a}^{-1}$ of $\mathrm{N}$ and $\mathrm{K}_{2} \mathrm{O}$, where as for LAR, there was no difference between the doses of fertilizer, with a mean value of $3.4 \mathrm{~kg} \mathrm{DM} \mathrm{ha-1}$ day $^{-1}$. Stronger responses of Urochloa ruziziensis to nitrogen and potassium fertilization occurred during summer 2, both due to the availability of environmental factors for the plant development and growth and the better response (adaptation) of the fodder plant to the tested doses of fertilizer.

Urochloa ruziziensis is a forage plant with a high potential for the production of DM for animal consumption, because it had high FAR (mean of 126 $\mathrm{kg} \mathrm{ha}^{-1}$ day $^{-1}$ in summers 1 and 2) and LAR (mean of $69 \mathrm{~kg} \mathrm{ha}^{-1}$ day $^{-1}$ in summers 1 and 2) values during summer. It is characterized by a high seasonality of forage production $(95 \%$ of the production obtained during summer; the values were very low in autumn: mean FAR and LAR values of $6.2 \mathrm{~kg} \mathrm{ha}^{-1}$ day $^{-}$ ${ }^{1}$ and $3.4 \mathrm{~kg} \mathrm{ha}^{-1}$ day $^{-1}$, respectively) compared to Urochloa decumbens (FAGUNDES et al., 2005a), whose mean FAR values were $67 \mathrm{~kg} \mathrm{ha}^{-1}$ day $^{-1}$ and $18 \mathrm{~kg} \mathrm{ha}^{-1}$ day $^{-1}$ during summer and autumn, respectively.

\section{Conclusions}

The PHY and LER of Urochloa ruziziensis leaves benefited from the effect of nitrogen and potassium fertilization up to a mean $\mathrm{N}$ and $\mathrm{K}_{2} \mathrm{O}$ dose of 220 $\mathrm{kg} \mathrm{ha}^{-1}$, and the stem elongation rate was positively affected by $\mathrm{N}$ and $\mathrm{K}_{2} \mathrm{O}$ fertilization up to a dose of $360 \mathrm{~kg} \mathrm{ha}^{-1}$ duringsummer.

Nitrogen and potassium fertilization exerts a positive effect on the variables associated with the tillering (density and percentages of appearance and mortality) of Urochloa ruziziensis during spring and summer.

The senescence rate of this fodder plant is accelerated with increased doses of nitrogen and potassium, and the rates of forage and leaf accumulation benefited from mean annual $\mathrm{N}$ and $\mathrm{K}_{2} \mathrm{O}$ doses greater than $140 \mathrm{~kg} \mathrm{ha}{ }^{-1}$ during the summer. 
Urochloa ruziziensis is a fodder plant with a high potential for DM production during the summer and is characterized by a high seasonality of forage production.

\section{Acknowledgements}

This study was financed in part by the Coordenação de Aperfeiçoamento de Pessoal de Nível Superior - Brasil (CAPES) - Finance Code 001

\section{References}

ALEXANDRINO, E.; NASCIMENTO JÚNIOR, D.; REGAZZI, A. J.; MOSQUIM, P. R.; ROCHA, F. C.; SOUZA, D. P. Características morfogênicas e estruturais na rebrotação da Brachiaria brizantha cv. Marandu submetida a três doses de nitrogênio e frequências de corte. Acta Scientiarum, Maringá, v. 27, n. 1, p. 17-24, 2004.

ALVES, L. W. R. Produção e dinâmica de degradação da fitomassa de planta para cobertura do solo no sistema plantio direto em Paragominas, PA. Macapá: EMBRAPA, 2015. 20 p. (Boletim de Pesquisa e Desenvolvimento, n. 90).

BASSO, K. C.; CECATO, U.; LUGÃO, S. M. B.; GOMES, J. A. N.; BARBERO, L. M.; MOURÃO, G. B. Morfogênese e dinâmica do perfilhamento em pastos de Panicum maximumJacq. cv. IPR-86 Milênio submetido a doses de nitrogênio. Revista Brasileira de Saúde e Produção Animal, Salvador, v. 11, n. 4, p. 976-989, 2010.

BIRCHAM, J. S.; HODGSON, J. The influence of sward condition on rates of herbage growth and senescence in mixed swards under continuous stoking management. Grass and Forage Society, Wiley, v. 38, n. 4, p. 323-331, 1983. DOI: 1 0.1111/j.1365-2494.1983.tb01656.x

BRAZ, T. G.; FONSECA, D. M.; FREITAS, F. P.; MARTUSCELLO, J. A.; SANTOS, M. E. R.; SANTOS, M. V.; PEREIRA, V. V. Morphogenesis of Tanzania guinea grass under nitrogen doses and plant densities. Revista Brasileira de Zootecnia, Viçosa, MG, v. 40, n. 7 p. 14201427, 2011. DOI: 10.1590/S1516-35982011000700004

BULLOCK, J. M. Plant competition and population dynamics. In: HODGSON, J.; ILLIUS A. W. (Ed.). The ecology and management of grazing systems. London: CAB International, 1996. p. 69-100.
CAMPOS, F. P.; NICÁCIO, D. R. O.; SARMENTO, P.; CRUZ, M. C. P.; SANTOS, T. M.; FARIA, A. F. G.; FERREIRA, M. E.; CONCEIÇÃO, M. R. G.; LIMA, C. G. Chemical composition and in vitro ruminal digestibility of hand-plucked samples of Xaraés palisade grass fertilized with incremental levels of nitrogen. Animal Feed Science and Technology, Amsterdam, v. 215, p. 1-12, 2016. DOI: 10.1016/j.anifeedsci.2015.12.013

COLOZZA, M. T.; KIEHL, J. C.; WERNER, J. C.; SCHAMMASS, E. A. Respostas de Panicum maximum cultivar Aruana a doses de N. Boletim de Indústria Animal, Nova Odessa, v. 57, n. 1, p. 2 1-32, 2000.

Da SILVA, S.C. Produção de leite em pasto: o processo e sua intensificação. São Paulo: Casa do Produtor, 2016 Disponível em: http://www.esalq.usp.br/cprural. Acesso em: 4 maio 2018.

DE-POLLI, H. Manual de adubação para o Estado do Rio de Janeiro. Itaguaí: UFRRJ, 1990. 179 p.

FAGUNDES, J. L.; FONSECA, D. M.; GOMIDE, J. A.; NASCIMENTO JUNIOR, D.; VITOR, C. M. T.; MORAIS, R. V.; MISTURA, C.; REIS, G. C.; MARTUSCELLO, J. A. Acúmulo de forragem em pastos de Brachiaria decumbens adubados com nitrogênio. Pesquisa Agropecuária Brasileira, Brasília, v. 40, n. 4, p. 397-403, 2005a.

FAGUNDES, J. L.; FONSECA, D. M.; MISTURA, C.; MORAIS, R. V.; VITOR, C. M. T.; REIS, G. C.; CASA GRANDE, D. R.; SANTOS, M. E. R. Índice de área foliar, densidade de perfilhos e acúmulo de forragem em pastagem de capim-braquiária adubada com nitrogênio. Boletim de Indústria Animal, Nova Odessa, v. 62, n. 2, p. 125-133, 2005b.

FONSECA, D. M.; MARTUSCELlO, J. A. Plantas forrageiras. Viçosa, MG: UFV, 2010. $460 \mathrm{p}$.

GOMIDE, J. A.; CÂNDIDO, M. J. D.; ALEXANDRINO, E. As interfaces solo-planta-animal da exploração da pastagem. In: EVANGELISTA, A. R.; REIS, S. T.; GOMIDE, E. M. (Ed.). Forragicultura e pastagem: temas em evidência - sustentabilidade. Lavras: UFLA, 2003. p. 75-116.

HODGSON, J. Grazing management: science into practice. New York: Wiley, 1990. 203 p.

INSTITUTO BRASILEIRO DE GEOGRAFIA E ESTATÍSTICA - IBGE. Censo agropecuário 2017. Brasil, Grandes Regiões e Unidades da Federação. Primeiros Resultados. Disponível em: https://censos.ibge.gov. br/ agro/2017. Acesso em: 17 dez. 2018.

INSTITUTO NACIONAL DE METEOROLOGIA INMET. Banco de dados meteorológicos para ensino e 
pesquisa. 2012. Disponível em: http://www.inmet.gov. br/sonabra/maps/automaticas.php. Acesso em: 30 mar. 2012.

LIMA, J. E. S.; NASCENTE, A. S.; LEANDRO, W. M.; SILVEIRA, P. M. Urochloa ruziziensis responses to sources and doses of urea. Revista Brasileira de Engenharia Agrícola e Ambiental, Campina Grande, v. 20, n. 5, p. 401-407, 2016. DOI: 10.1590/1807-1929/ agriambi.v20n5p401-407

LOPES, M. N.; CÂNDIDO, M. J. D.; POMPEU, R. C. F. F.; SILVA, R. G.; LOPES, J. W. B.; FERNANDES, F. R. B.; LACERDA, C. F.; BEZERRA, F. M. L. Fluxo de biomassa em capim-massai durante o estabelecimento e rebrotação com e sem adubação nitrogenada. Revista Ceres, Viçosa, MG, v. 60, n. 3. p. 363-371, 2013.

MARTUSCELLO, J. A.; FONSECA, D. M.; NASCIMENTO JÚNIOR, D.; SANTOS, P. M.; RIBEIRO JUNIOR, J. I.; CUNHA, D. N. F. V.; MOREIRA, L. M. Características morfogênicas e estruturais do capimxaraés submetido à adubação nitrogenada e desfolhação. Revista Brasileira de Zootecnia, Viçosa, MG, v. 34, n. 5, p. 475-1482, 2005.

MORAIS, R. V.; FONSECA, D. M.; NASCIMENTO JÚNIOR, D.; RIBEIRO JÚNIOR, J. I.; FAGUNDES, J. L.; MOREIRA, L. M.; MISTURA, C.; MARTUSCELLO, J. A. Demografia de perfilhos basilares em pastagem de Brachiaria decumbens adubada com nitrogênio. Revista Brasileira de Zootecnia, Viçosa, MG, v. 35, n. 2, p. 380388, 2006.

MOREIRA, L. M.; MARTUSCELLO, J. A.; FONSECA, D. M.; MISTURA, C.; MORAIS, R. V.; RIBEIRO JÚNIOR, J. I. Perfilhamento, acúmulo de forragem e composição bromatológica do capim-braquiária adubado com nitrogênio. Revista Brasileira de Zootecnia, Viçosa, MG, v. 38, n. 9, p. 675-1684, 2009.

NABINGER, C. Princípios da exploração intensiva de pastagens. In: PEIXOTO, A. M.; MOURA, J. C.; FARIA, V. P. (Ed.). Produção de bovinos a pasto. Piracicaba: Fundação de Estudos Agrários Luiz de Queiroz, 1996. p. 15-95.

OLIVEIRA, A. B.; PIRES, A. J. V.; MATOS NETO, U.; CARVAlHO, G. G. P.; VELOSO, C. M.; SILVA, F. F. Morfogênese do capim-tanzânia submetido a adubações e intensidades de corte. Revista Brasileira de Zootecnia, Viçosa, MG, v. 36, n. 4, p. 1006-1013, 2007.

PEREIRA, V. V.; FONSECA, D. M.; MARTUSCELLO, J. A.; BRAZ, T. G. S.; SANTOS, M. V.; CECON, P. R. Características morfogênicas e estruturais de capimmombaça em três densidades de cultivo adubado com nitrogênio. Revista Brasileira de Zootecnia, Viçosa, MG, v. 40, n. 12, p. 2681-2689, 2011.

POMPEU, R. C. F. F.; CÂNDIDO, M. J. D.; LOPES, M. N.; GOMES, F. H. T.; LACERDA, C. F.; AQUINO, B. F.; MAGALHÃES, J.A. Características morfofisiológicas do capim-aruana sob diferentes doses de nitrogênio. Revista Brasileira de Saúde e Produção Animal, Salvador, v. 11, n. 4, p. 1187-1210, 2010.

PORTZ, A.; RESENDE, A. S.; TEIXEIRA, A. J.; ABBOUD, A. C. S.; MARTINS, C. A. C.; CARVALHO, C. A. B.; LIMA, E.; ZONTA, E.; PEREIRA, J. B. A.; BALIEIRO, F. C.; ALMEIDA, J. C. C.; SOUZA, J. F.; GUERRA, J. G. M.; MACEDO, J. R.; SOUZA, J. N.; FREIRE, L. R.; VASCONCELOS, M. A. S.; LEAL, M. A. A.; FERREIRA, M. B. C.; MANHÃES, M.; GOUVEA, R. F.; BUSQUET, R. N. B.; BHERING, S. B. Recomendações de adubos, corretivos e de manejo da matéria orgânica para as principais culturas de Estado do Rio de Janeiro. In: FREIRE, L. R.; BALIEIRO, F. C.; ANJOS, L. H. C.; PEREIRA, M. G.; LIMA, E.; GUERRA, J. G. M.; FERREIRA, M. B. C.; LEAL, M. A. A.; CAMPOS, D. V. B.; POLIDORO, J. C. Manual de calagem e adubação do Estado do Rio de Janeiro. Seropédica: UFRRJ, 2013. Cap. 14, p. 257-414.

RAMOS, D. P.; CASTRO, A. F.; CAMARGO, M. N. Levantamento detalhado de solos da área da Universidade Federal Rural do Rio de Janeiro. Pesquisa Agropecuária Brasileira, Brasília, v. 8, p. 1-27, p. 1-27, 1973.

SALES, E. C. J.; REIS, S. T.; ROCHA JÚNIOR, V. R.; MONÇÃO, F. P.; MATOS, V. M.; PEREIRA, D. A.; AGUIAR, A. C. R.; ANTUNES, A. P. S. Características morfogênicas e estruturais da Brachiaria brizanthacv. Marandu submetida a diferentes doses de nitrogênio e alturas de resíduos. Semina: Ciências Agrárias, Londrina, v. 35, n. 5, p. 2673-2684, 2014.

SILVA, C. C. F.; BONOMO, P.; PIRES, A. J. V.; MARANHÃO, C. M. A.; PATÊS, N. M. S.; SANTOS, L. C. Características morfogênicas e estruturais de duas espécies de braquiária adubadas com diferentes doses de nitrogênio. Revista Brasileira de Zootecnia, Viçosa, MG, v. 38, n. 4, p. 657-661, 2009.

SILVA, T. C. da; PERAZZO, A. F.; MACEDO, C. H. O.; BATISTA, E. D.; PINHO, R. M. A.; BEZERRA, H. F. C.; SANTOS, E. M. Morfogênese e estrutura de Brachiaria decumbensem resposta ao corte e adubação nitrogenada. Archivos de Zootecnia, Córdoba, v. 61, n. 233, p. 91-102, 2012.

STATISTICAL ANALYSIS SYSTEM INSTITUTE SAS Institute. SAS/STAT. User's Guide Statistics, 9.2. Cary: SAS Institute, 2004. 
TEIXEIRA, F. A.; PIRES, A. J. V.; SILVA, F. F.; FRIES, D. D.; REZENDE, C. P.; COSTA, A. C. P. R.; SANTOS, T. C. S.; NASCIMENTO, P. V. N. Nitrogen fertilization strategies, morphogenetic and structural features in Brachiaria decumbens deferred for 95 days. Semina: Ciências Agrárias, Londrina, v. 35, n. 2, p. 987-998, 2014. DOI: $10.5433 / 1679-0359.2014 v 35 n 2 p 987$
THORNTHWAITE, C. W.; MATHER, J. R. The water balance. Centerton: Drexel Institute of Technology, Laboratory of Climatology, 1955. 104 p. (Publications in Climatology, v. VIII, n. 1).

WOLFINGER, R. D. Covariance structure selection in general mixed models. Communications in Statistics Simulation and Computation, London, v. 22, n. 4, p. 1079-1106, 1993. DOI: 10.1080/03610919308813143 
